\title{
Neurofibromatosis Type 2 (NF2) and the Implications for Vestibular Schwannoma and Meningioma Pathogenesis
}

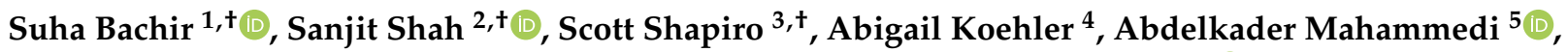 \\ Ravi N. Samy ${ }^{3}$, Mario Zuccarello ${ }^{2}$, Elizabeth Schorry ${ }^{1}$ and Soma Sengupta ${ }^{4, *}$ (i) \\ 1 Department of Genetics, Cincinnati Children's Hospital, Cincinnati, OH 45229, USA; \\ suha.bachir@cchmc.org (S.B.); elizabeth.schorry@cchmc.org (E.S.) \\ 2 Department of Neurosurgery, University of Cincinnati, Cincinnati, OH 45267, USA; \\ Sanjit.Shah@UCHealth.com (S.S.); Mario.Zuccarello@UCHealth.com (M.Z.) \\ 3 Department of Otolaryngology, University of Cincinnati, Cincinnati, OH 45267, USA; \\ scott.shapiro@cchmc.org (S.S.); Ravi.Samy@UCHealth.com (R.N.S.) \\ 4 Department of Neurology, University of Cincinnati, Cincinnati, OH 45267, USA; koehleai@ucmail.uc.edu \\ 5 Department of Radiology, University of Cincinnati, Cincinnati, OH 45267, USA; mahammar@ucmail.uc.edu \\ * Correspondence: sengupsm@ucmail.uc.edu \\ + These authors contributed equally.
}

check for updates

Citation: Bachir, S.; Shah, S.; Shapiro, S.; Koehler, A.; Mahammedi, A.; Samy, R.N.; Zuccarello, M.; Schorry, E.; Sengupta, S. Neurofibromatosis Type 2 (NF2) and the Implications for Vestibular Schwannoma and Meningioma Pathogenesis. Int. J. Mol. Sci. 2021, 22, 690. https://doi.org/ $10.3390 /$ ijms 22020690

Received: 7 December 2020 Accepted: 7 January 2021 Published: 12 January 2021

Publisher's Note: MDPI stays neutral with regard to jurisdictional clai$\mathrm{ms}$ in published maps and institutional affiliations.

Copyright: (C) 2021 by the authors. Licensee MDPI, Basel, Switzerland. This article is an open access article distributed under the terms and conditions of the Creative Commons Attribution (CC BY) license (https:// creativecommons.org/licenses/by/ $4.0 /)$.

\begin{abstract}
Patients diagnosed with neurofibromatosis type 2 (NF2) are extremely likely to develop meningiomas, in addition to vestibular schwannomas. Meningiomas are a common primary brain tumor; many NF2 patients suffer from multiple meningiomas. In NF2, patients have mutations in the NF2 gene, specifically with loss of function in a tumor-suppressor protein that has a number of synonymous names, including: Merlin, Neurofibromin 2, and schwannomin. Merlin is a $70 \mathrm{kDa}$ protein that has 10 different isoforms. The Hippo Tumor Suppressor pathway is regulated upstream by Merlin. This pathway is critical in regulating cell proliferation and apoptosis, characteristics that are important for tumor progression. Mutations of the NF2 gene are strongly associated with NF2 diagnosis, leading to benign proliferative conditions such as vestibular schwannomas and meningiomas. Unfortunately, even though these tumors are benign, they are associated with significant morbidity and the potential for early mortality. In this review, we aim to encompass meningiomas and vestibular schwannomas as they pertain to NF2 by assessing molecular genetics, common tumor types, and tumor pathogenesis.
\end{abstract}

Keywords: neurofibromatosis type 2 (NF2); meningiomas; vestibular schwannomas

\section{Neurofibromatosis Type 2 (NF2): Introduction and Genetic Overview}

Neurofibromatosis type 2 (NF2) is an autosomal dominant condition caused by pathogenic variants in the NF2 gene (NF2; MIM \# 607379) causing loss of function of the tumor suppressor protein, Merlin [1-3]. NF2 is characterized by central and peripheral nervous system (CNS and PNS) tumors [3].

The incidence of NF2 is around one in 25,000 with a penetrance of 95\% [4]. Over half of patients with NF2 are reported to have a de novo mutation and around one-third are mosaic [1]. Symptom onset is usually by age 20 with approximately $90 \%$ of patients having the pathognomonic feature of the disease: bilateral vestibular schwannomas. Around 50\% of patients also have meningiomas [4]. Other common tumors include spinal schwannomas, ependymomas, and dermal schwannomas [5].

Clinical diagnostic criteria for NF2 have evolved over time, and a new revision is due to be published in the near future. The clinical diagnostic criteria published in 2017 are detailed below in Table 1 [6], and tumor types are summarized in Table 1. Interestingly, NF2 is genetically unrelated to the more common neurofibromatosis type 1 (NF1) which is due to pathogenic variants of the tumor suppressor NF1 gene on chromosome 17. It is, 
however, closely related to schwannomatosis, due to variants in either INI1 (SMARCB1) or LZTR1, which are closely located to NF2 on chromosome 22. As the predominant tumor type in NF2 is the schwannoma (and not neurofibroma), there has been discussion that the more appropriate name for NF2 might be Schwannomatosis Predisposition Syndrome (SPS), merlin type.

Treatment of NF2 involves the combination of medical surveillance through physical exam, audiometric testing, imaging, and surgical intervention when indicated. Patients are managed by a multidisciplinary team including neurotologists, neurologists, audiologists, oncologists, geneticists, neurosurgeons, and ophthalmologists [7].

Table 1. Clinical diagnosis criteria for neurofibromatosis type 2 (NF2) $[6,8]$.

1. Bilateral vestibular schwannomas $<70$ years of age.

2. Unilateral vestibular schwannoma $<70$ years and a first-degree relative with NF2.

3. Any two of the following: meningioma, schwannoma (non-vestibular), ependymoma, cerebral calcification, cataract $A N D$ first-degree relative to NF2 OR unilateral vestibular schwannoma and negative LZTR1 testing. Note: recent data have excluded glioma in the criteria.

4. Multiple meningiomas and unilateral vestibular schwannoma or any two of the following: schwannoma (non-vestibular), neurofibroma, glioma, cerebral calcification, cataract.

5. Constitutional or mosaic pathogenic NF2 gene mutation from the blood or by the identification of an identical mutation from two separate tumors in the same individual.

\section{NF2; Molecular Genetics}

NF2 is a tumor suppressor gene comprised of 17 exons with 2 splicing isoforms that is positioned on chromosome 22q12.2. It encodes the 595 amino acid protein, Merlin [3]. Merlin is a member of the Ezrin/Radixin/Moesin (ERM) family of membranecytoskeleton-linking proteins with an enigmatic role, although there is evidence to suggest it is involved in stabilizing the membrane cytoskeleton interface by inhibiting signals involving PI3kinase/Akt, Raf/MEK/ERK, and mTOR signaling pathways $[7,9,10]$. The mechanism of tumorigenesis in NF2 has yet to be fully elucidated, although loss of heterozygosity involving allelic loss of NF2 is thought to be a likely mode, as evidenced by work on skin tumors, vestibular schwannomas, and meningiomas in NF2 patients [11,12]. Other data have suggested an epigenetic role involving transcriptional inactivation of the NF2 gene from hyper-methylation as another possible tumorigenesis mechanism [13].

Typically, NF2-affected family members experience the same type and location of the NF2 germ-line variant, in which phenotypic expression of NF2 correlates amongst family members. Intra-familial similarity and the severity of phenotype is significant as variations in phenotype can be associated with mutations causing truncated protein expression [4]. Stochastic or epigenetic factors are certainly at play as evidenced by phenotypic variability seen in monozygotic twins [14]. Severity is categorized by early age of onset, hearing loss, and increased numbers of meningiomas [2,3]. Nonsense and missense variants are associated with a more severe and mild phenotype, respectively, whereas splice-site variants are more variable $[15,16]$. Incidentally, there are reports in the literature of mutations at the 5-prime end of the NF2 gene that are associated with increased intracranial meningiomas [6]. This genotype-phenotype correlation highlights the importance of offering genetic testing. Next-generation sequencing of all 17 coding exons of the NF2 gene is the best molecular test with up to $90 \%$ variant detection rate with a positive NF2 family history; a lower detection rate ranging between $25-60 \%$ is present in sporadic cases, likely due to somatic mosaicism [1,17]. When genetic testing is offered early to patients with suspected NF2, it provides useful prognostic information and a more tailored therapeutic approach. Selvanatham et al. performed molecular genetic analysis on 268 NF2 patients and found that those with nonsense variants had a more severe phenotype including more meningiomas and spinal tumors. In fact, they were diagnosed at an earlier age, which sadly may not result in an improved overall outcome but did allow earlier intervention [18]. 


\section{NF2: Tumor Types}

The tumor types associated with NF2 including incidence, clinical presentation, histological, imaging, and treatment/complications are summarized in Table 2 [4,19-21]. The neuroimaging hallmarks give rise to the acronym MISME, which describes multiple inherited schwannomas, meningiomas, and ependymomas [22].

Table 2. Characteristics of NF2 tumor type.

\begin{tabular}{|c|c|c|c|c|c|c|}
\hline NF2 Tumor Types & $\%$ & Clinical Presentation & Histology & Imaging & Treatment & Complications \\
\hline $\begin{array}{c}\text { Vestibular } \\
\text { Schwannomas }\end{array}$ & $\sim 90 \%$ & $\begin{array}{l}\text { Tinnitus } \\
\text { Hearing loss } \\
\text { Ataxia }\end{array}$ & $\begin{array}{l}\text { Antoni A, B regions } \\
\text { Verocay bodies } \\
\text { Hyalinzed vessels }\end{array}$ & $\begin{array}{c}\text { Often bilateral. Slightly T1 } \\
\text { hypointense }(63 \%) \text { or isointense } \\
(37 \%) \text {. Heterogeneously T2 } \\
\text { hyperintense (Antoni A: } \\
\text { relatively low, Antoni B: high), } \\
\text { cystic degenerative areas may } \\
\text { be present if large tumor. } \\
\text { Intense contrast enhancement } \\
\text { on T1 C+ (Gd) }\end{array}$ & $\begin{array}{l}\text { Radiosurgery } \\
\text { Chemotherapy; } \\
\text { Bevacizumab }\end{array}$ & $\begin{array}{c}\text { Facial nerve } \\
\text { injury } \\
\text { Malignant } \\
\text { transformation }\end{array}$ \\
\hline $\begin{array}{l}\text { Peripheral } \\
\text { Schwannomas } \\
\text {-Tumorlets } \\
\text {-Plexiform }\end{array}$ & $\sim 70 \%$ & $\begin{array}{l}\text { Neuropathic pain } \\
\text { Loss of sensation } \\
\text { Weakness } \\
\text { Tumors on skin, head } \\
\text { and neck region } \\
\text { (Plexiform) }\end{array}$ & $\begin{array}{l}\text { Antoni A, B regions } \\
\text { Verocay bodies } \\
\text { Hyalinzed vessels } \\
\text { Infiltration of nerve }\end{array}$ & $\begin{array}{l}\text { T1: } 75 \% \text { are isointense, } 25 \% \text { are } \\
\text { hypointense. T2: more than } 95 \% \\
\text { are hyperintense, often with } \\
\text { mixed signal. Intense contrast } \\
\text { enhancement on } \mathrm{T} 1 \mathrm{C}+(\mathrm{Gd})\end{array}$ & $\begin{array}{l}\text { Intraneural } \\
\text { dissection } \\
\text { Excision }\end{array}$ & $\begin{array}{l}\text { Rarely undergo } \\
\text { malignant } \\
\text { transformation } \\
\text { although high } \\
\text { risk of nerve } \\
\text { infiltration }\end{array}$ \\
\hline Meningiomas & $\begin{array}{c}\sim 50 \% \\
(20 \% \text { are } \\
\text { in kids) }\end{array}$ & $\begin{array}{l}\text { Headache } \\
\text { Seizure }\end{array}$ & $\begin{array}{c}\text { Fibrous morphology } \\
\text { Psamomma } \\
\text { Bodies } \\
\text { High mitotic index }\end{array}$ & $\begin{array}{l}\text { Intense and homogeneous } \\
\text { enhancement. Frequent cystic } \\
\text { components } \\
\text { Can be multiple } \\
\text { Present in unusual locations: } \\
\text { craniocervical junction. }\end{array}$ & $\begin{array}{c}\text { Surgical excision } \\
\text { Radiosurgery } \\
\text { Current clinical } \\
\text { trial: mTORC1/2 } \\
\text { inhibitor } \\
\text { AZD2014 } \\
\text { (NCT02831257, } \\
\text { NCT03071874) }\end{array}$ & $\begin{array}{l}\text { Malignant } \\
\text { transformation } \\
\text { Invasion to } \\
\text { vascular brain } \\
\text { structures } \\
\text { Compression } \\
\text { effect }\end{array}$ \\
\hline $\begin{array}{c}\text { Ependymoma } \\
\text { Glial }\end{array}$ & $\sim 30 \%$ & Asymptomatic & $\begin{array}{c}\text { Perivascular } \\
\text { pseudorosettes } \\
\text { Ependymal rosettes }\end{array}$ & $\begin{array}{l}\text { Usually spinal intramedullary } \\
\text { (not } \\
\text { intracranial/intraventricular). } \\
\text { "String of pearls" appearance } \\
\text { along the spinal cord and cauda } \\
\text { equina. }\end{array}$ & $\begin{array}{l}\text { Monitoring/ } \\
\text { surveillance } \\
\text { Surgical resection } \\
\text { if symptomatic }\end{array}$ & $\begin{array}{l}\text { Malignant } \\
\text { transformation } \\
\text { is rare }\end{array}$ \\
\hline Menigioangiomatosis & rare & $\begin{array}{c}\text { Headache } \\
\text { Seizures } \\
\text { Behavioral changes } \\
\text { Cortical blindness } \\
\text { Paresis }\end{array}$ & $\begin{array}{c}\text { Plaque like } \\
\text { leptomeningeal and } \\
\text { perivascular } \\
\text { proliferation } \\
\text { Fibroblastic and } \\
\text { meningothelial } \\
\text { appearing cells }\end{array}$ & $\begin{array}{c}\text { Cortical/subcortical white } \\
\text { matter mass characterized by } \\
\mathrm{Ca}^{++} \text {, enhancing } \\
\text { meningovascular proliferation. } \\
\text { Most common in temporal and } \\
\text { frontal lobes. }\end{array}$ & Surgical excision & $\begin{array}{l}\text { Intracerebral } \\
\text { hemorrhage }\end{array}$ \\
\hline $\begin{array}{c}\text { Glial micro } \\
\text { hamartomas }\end{array}$ & Common & Asymptomatic & $\begin{array}{l}\text { Atypical pleomorphic } \\
\text { nuclei, Occasional } \\
\text { multi-nucleation, } \\
\text { Eosinophilic } \\
\text { cytoplasm }\end{array}$ & $\begin{array}{l}\text { Cortical hyperintense } \\
\text { T2/FLAIR lesions } \\
\text { "Transmantle sign" }\end{array}$ & $\begin{array}{l}\text { Surveillance and } \\
\text { monitoring }\end{array}$ & None \\
\hline
\end{tabular}

Note: \% refers to incidence.

\section{NF2 Meningioma Pathogenesis}

Meningiomas can be intracranial or spinal in NF2. These are common primary intracranial dural-based tumors arising from arachnoid cap cells, with an incidence of $7-8 / 100,000$ people/year; they account for $37.1 \%$ of primary intracranial tumors [23-25]. The clinical presentation of meningioma ranges from incidental discovery to headaches, visual deficits, cranial nerve dysfunction, and seizures due to mass effect or cortical irritation (please see Figures 1 and 2 for an example of meningiomas in a patient). According to World Health Organization (WHO) classification, 15 subtypes of meningioma exist, with grades corresponding to histopathologic analysis [26,27]. However, studies have demonstrated that WHO grading correlates poorly with prognosis as grade alone is not entirely predictive of recurrence and malignant transformation [28,29], creating a role for molecular genetics both in meningioma treatment and prognostication. An estimated $50-75 \%$ of patients with NF2 develop meningiomas; in contrast to sporadic meningiomas, these are often Grade II or III, have a worse prognosis, and higher rate of recurrence [30-32]. 


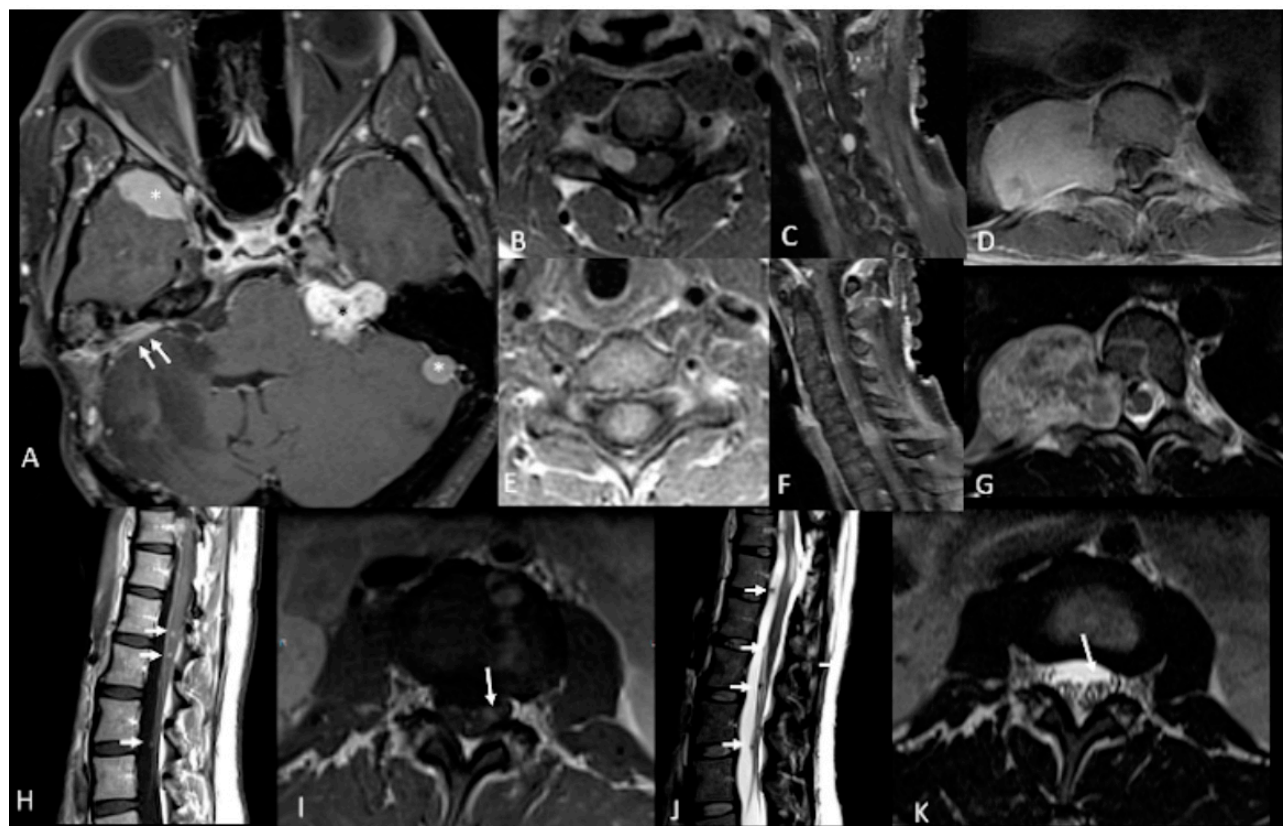

Figure 1. 46-year-old woman with neurofibromatosis type 2 (NF2). Contrast-enhanced T1-weighted-Fat saturation MR images (A,F,I) show avidly enhancing schwannoma involving left cerebellopontine angle and internal auditory canal (black asterisk in (A)) and avidly enhancing meningiomas in the right anterior temporal convexity, sphenoid wing, and left lateral posterior fossa (white asterisks in (A)). Post-operative changes from right suboccipital craniotomy and mastoidectomy with residual meningioma (white arrows in (A)). Avidly enhancing dumbbell-shaped right C5 intradural schwannoma extending through right $\mathrm{C} 5$ foramen $(\mathbf{B}, \mathbf{C})$. Large avidly enhancing right paraspinal $\mathrm{T} 10$ schwannoma extending through right T10 foramen (D) with associated heterogenous T2 hyperintensity on axial T2-weighted image (G). Avidly enhancing intramedullary C6 ependymoma $(\mathbf{E}, \mathbf{F})$. Numerous multilevel tiny enhancing rounded nodules along the cauda equina $(\mathbf{H}, \mathbf{I})$ consistent with schwannomas which demonstrate T2 hypointensity on axial and sagittal T2-weighted images (white arrows in $(\mathbf{J}, \mathbf{K}))$.
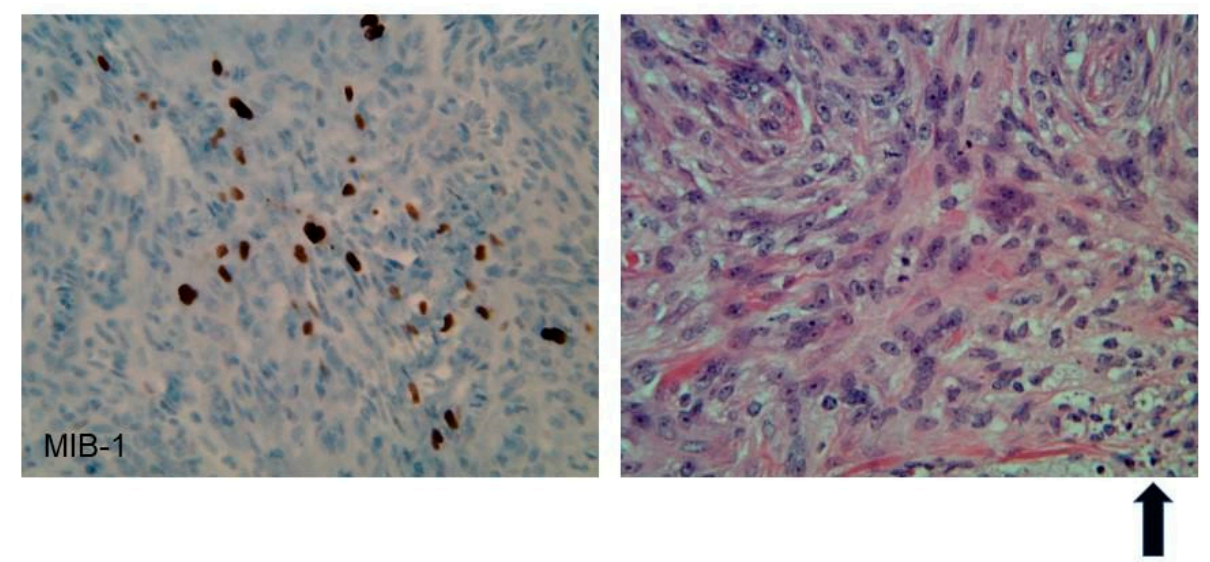

Figure 2. Immunohistochemistry of an atypical meningioma (WHO Grade II) from an NF2 patient. Left panel: 40× magnification, MIB-1(Ki67) nuclear immunostain shows an elevated index (25\%). Right panel: $40 \times$ H\&E shows increased cellularity, prominent nucleoli, mitoses, and necrosis (as represented in the bottom right hand section and highlighted by the arrow in bold).

Loss of chromosome 22 has been widely implicated in the pathogenesis of meningioma, sharing a common pathway for tumorigenesis with NF2 patients due to the presence of neurofibromin on chromosome 22q12.2. Deletions, nonsense mutations, splice site mutations, and translocations in NF2/Merlin are identified in 50-60\% of the general population of patients with meningiomas, and loss of chromosome 22 in tumor tissue can be seen in $40-80 \%$ of patients developing meningioma $[23,24]$. The exact mechanism by which loss 
of Merlin or chromosome 22 affects meningioma pathogenesis is not well understood, as both have been implicated to have a role in cytoskeletal remodeling; indeed, the production of junctional proteins E-cadherin and Zo-1 demonstrate a positive correlation with NF2/Merlin expression [33]. Furthermore, loss of chromosome 22 has been widely shown to activate oncogenic pathways with downstream targets such as Ras/mitogen-activated protein kinase, Notch, and mammalian target of rapamycin (mTOR) [34]. Notably, Bi et al. demonstrated that a mean of 23 NF2 mutations in high-grade gliomas compared to 11 in low-grade gliomas, suggesting a positive correlation between NF2 mutation rate and meningioma grade; this has been corroborated by additional studies $[23,30,33]$. Interestingly, a recent study by Angus and colleagues showed upregulation of erythropoietin producing hepatocellular receptor A2 (EPH-RA2), a downstream target MEK, in NF2 null mice; therapeutic interventions targeting such upstream signaling cascades of receptor tyrosine kinases may prove efficacious in treatment of NF2 related meningiomas [35].

In addition to the downstream effects of germline mutations to NF2, it is worth mentioning that a number of sporadic mutations have been implicated in the pathogenesis of meningioma. Several such mutations, including those to smoothened (SMO), tumor receptor-associated factor 7 (TRAF7), and phosphatidylinositol-4,5-bisphosphate 3 kinase catalytic subunit $\alpha$ (PIK3CA) are present in non-NF2 tumors and are mutually exclusive to mutations in NF2 [31,36-40]. Other genomic mutations, such as those to the telomerase reverse transcriptase (TERT) promoter region, demonstrate co-occurrence with NF2 mutations. While $6 \%$ of meningiomas possess TERT promoter mutations, nearly $80 \%$ of TERT mutations in meningioma co-occur with NF2 mutations and are associated with higher tumor grade and significantly decreased tumor-free progression [28]. The co-occurrence of such mutations provides valuable targets for prognostic evaluation and therapeutic intervention.

Elucidating the mechanism behind meningioma pathogenesis at a genetic level in neurofibromatosis 2 has clinical implications. A study by Clark et al. noted that NF2mutated meningiomas had a predilection for the posterior and lateral skull base, tentorium, and cerebral falx, while sporadic mutations, such as those to TRAF7 and SMO, had a tendency for anterior skull base presentation [31]. However, in NF2, meningiomas may also occur in the spinal canal, optic nerve sheaths, and cerebral ventricles. Unlike sporadic mutations, NF2 mutations are far more likely to produce multiple meningiomas and occur in a younger population; the mean age of meningioma diagnosis is 30 years. By age 70 , the cumulative incidence of meningioma is $80 \%$ in patients with proven NF2 mutations $[23,30,41,42]$. Understanding the genomic and molecular pathogenesis of NF2mutated meningiomas will provide insight into meningioma tumorigenesis as a whole and offer new avenues for efficacious therapies.

\section{NF2 Vestibular Schwannoma Pathogenesis}

Vestibular schwannomas (VS) are tumors derived from the Schwann cells of the vestibular branches of the vestibulocochlear nerve (cranial nerve VIII). The most common symptoms of VS are hearing loss, tinnitus, imbalance, facial numbness/paraesthesias, and facial paresis. Although benign histologically, they may compress the brainstem leading to hydrocephalus and neurologic emergency. Rarely, tumors may also cause hydrocephalus through poorly understood mechanisms that may involve high protein levels in the subarachnoid space [43]. Unilateral, sporadic tumors account for $95 \%$ of all VS, with bilateral VS being diagnostic of NF2 [44]. When possible, sporadic and NF-2 related VS should be distinguished from schwannomatosis, which is a distinct clinical and molecular entity which results in schwannomas throughout the body. Unlike NF2, it rarely involves the vestibular nerves. This can be difficult to distinguish in patients who present initially with non-vestibular schwannomas suggestive of shcwannomatosis and later develop bilateral VS, establishing the diagnosis of NF2. It may also be difficult in patients with non-vestibular schwannomas who are mosaic for NF2 [45].

Molecular studies have shown that VS develop as a result of inactivation of both alleles of the NF2 tumor suppressor gene. Consistent with the autosomal dominant in- 
heritance pattern, patients with NF2 inherit one mutated copy of the NF2 gene, and loss of heterozygosity (and all tumor suppressor function) in the Schwann cells allows for VS development [46-52]. NF2 is highly penetrant; patients who inherit an abnormal NF2 gene have a $95 \%$ chance of developing bilateral VS. Approximately $50 \%$ of NF2 patients have no family history of NF2, suggesting a significant proportion of cases arise due to new germ-line mutations, rather than through inheritance, and 33\% of these patients exhibit mosaicism, where the mutation takes place after conception and results in two separate cell lineages which may make mutations difficult to detect in peripheral blood analysis $[53,54]$. Tumor sequencing with matched peripheral blood analysis in patients with unilateral (sporadic) VS, demonstrate biallelic mutations in tumor specimens, which are not present in peripheral blood consistent with a "two-hit" theory for sporadic tumor development, which is consistent with the later presentation and less aggressive course of patients with sporadic tumors compared to their NF2 counterparts (please see Figure 3 for an example of NF2 VS) [55].

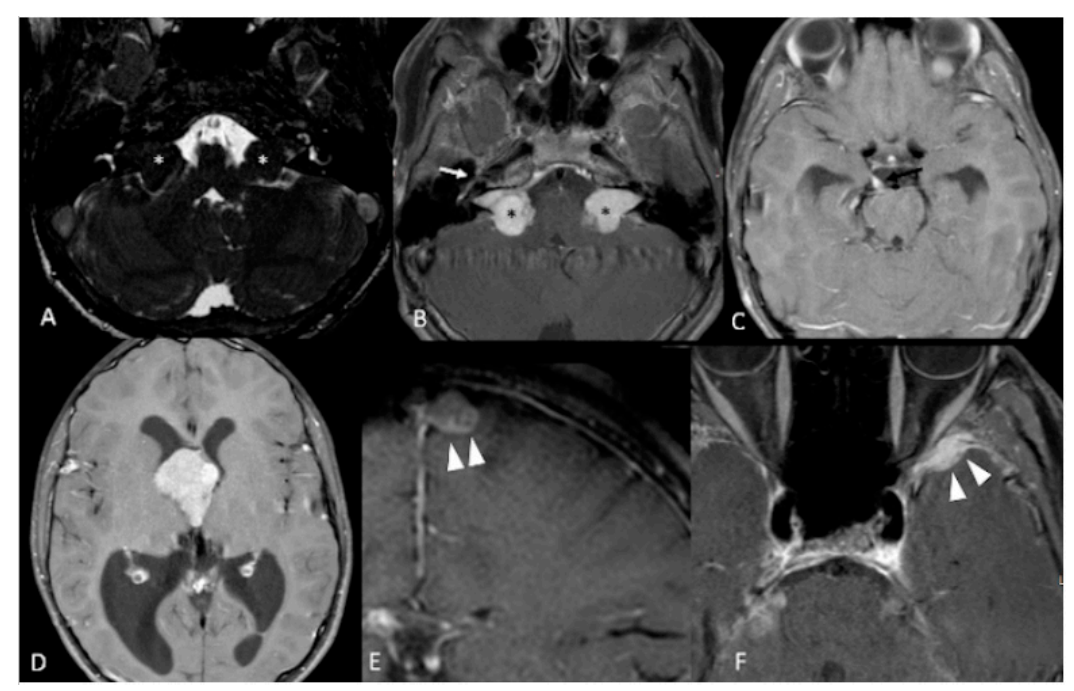

Figure 3. 12-year-old boy with NF2. Contrast-enhanced T1-weighted-Fat saturation MR images (B,F) show avidly enhancing masses involving cerebellopontine angles and internal auditory canals (black asterisks in (B)) with associated T2 hypointensity on axial high resolution T2 FIESTA (white asterisks in (A)), consistent with bilateral vestibular schwannomas. Also noted are asymmetric enhancement and enlargement of right geniculate ganglion of right CN7 (white arrow in (B)) and right CN3 (black arrow in (C)) consistent with additional schwannomas. Large third ventricular meningioma with obstructing hydrocephalus (D). Additional left parafalcine and left sphenoid wing meningiomas are noted (arrowheads in $(\mathbf{E}, \mathbf{F})$ ).

The NF2 gene is located on chromosome 22 at 22q12.2, and codes for the protein Merlin, which has also been called schwannomin $[47,48]$. Alterations in NF2 genes have been found in most but not all VS in both sporadic and syndromic-associated tumors. Interestingly, Merlin activity is nevertheless altered in cases where mutations are not detected, suggesting other post-translational events that can affect Merlin activity, or that some mutations are not being detected. The types of NF2 gene mutation has been loosely associated with mortality and disease severity in both NF2 associated and sporadic tumors $[55,56]$. For NF2 patients, nonsense or frameshift mutations which result in truncated protein products generally have more severe phenotype (earlier presentation and more aggressive tumors) than missense mutations [56], though not all studies have found such an association [47].

Though well-characterized as a tumor suppressor gene, the mechanisms behind Merlin's tumor suppressor functions have not been fully elucidated. Overexpression of Merlin in mouse models limits cell growth and cell transformation by the ras oncogene; growth control is lost when NF2 is inactivated in Schwann and meningeal cells. Merlin is structurally similar to proteins of the erythrocyte 4.1-related superfamily. These proteins 
link the actin cytoskeleton to the cell membrane, and Schwann cells from NF2 tumors show significant alteration in the actin cytoskeletal organization. Merlin is also known to localize to the cell membrane-cytoskeletal interface. It requires a dephosphorylated state to assume its active form; this phosphorylation status is dependent on the upstream activity of cyclic-AMP dependent protein kinase A, p21-activated kinases, and myosin phosphotate-1 protein activity. At the cell membrane-cytoskeletal interface, Merlin has been shown to interact with various cytosolic proteins, cell membrane components, cell-to-cell adhesion proteins, and cytoskeletal components. In addition to its actin-cytoskeletal effects, evidence exists for a role in intracellular pro-mitotic/anti-mitotic processes. Merlin has been shown to affect various downstream mitogenic signaling pathways such as the phosphoinositide-3 kinase (PI3K) and the mitogen-activated protein kinase (MAPK) signaling pathways. These pathways are known to be involved in oncogenesis, as well as being critical for cell growth and proliferation [57-64].

\section{The Current State and Future Directions for NF2 Related Meningiomas and Vestibular Schwannomas}

NF2 is a complicated neuro-cutaneous genetic disorder that can cause considerable morbidity (Figure 4). Apart from the vestibular schwannomas and meningiomas, ependymomas and spinal schwannomas can also occur in this patient population, however, this review is focusing on the first two diseases. More treatment options need to be available, as the current options are not curative. Surgical resection can have recurrence, and the current therapeutic options such as Bevacizumab or mTOR inhibitors do not produce a long-lasting effect in these patients. As discussed in the prior sections, as the molecular pathology is being unraveled, we will be able to design better drugs for the tumor types in NF2 patients.

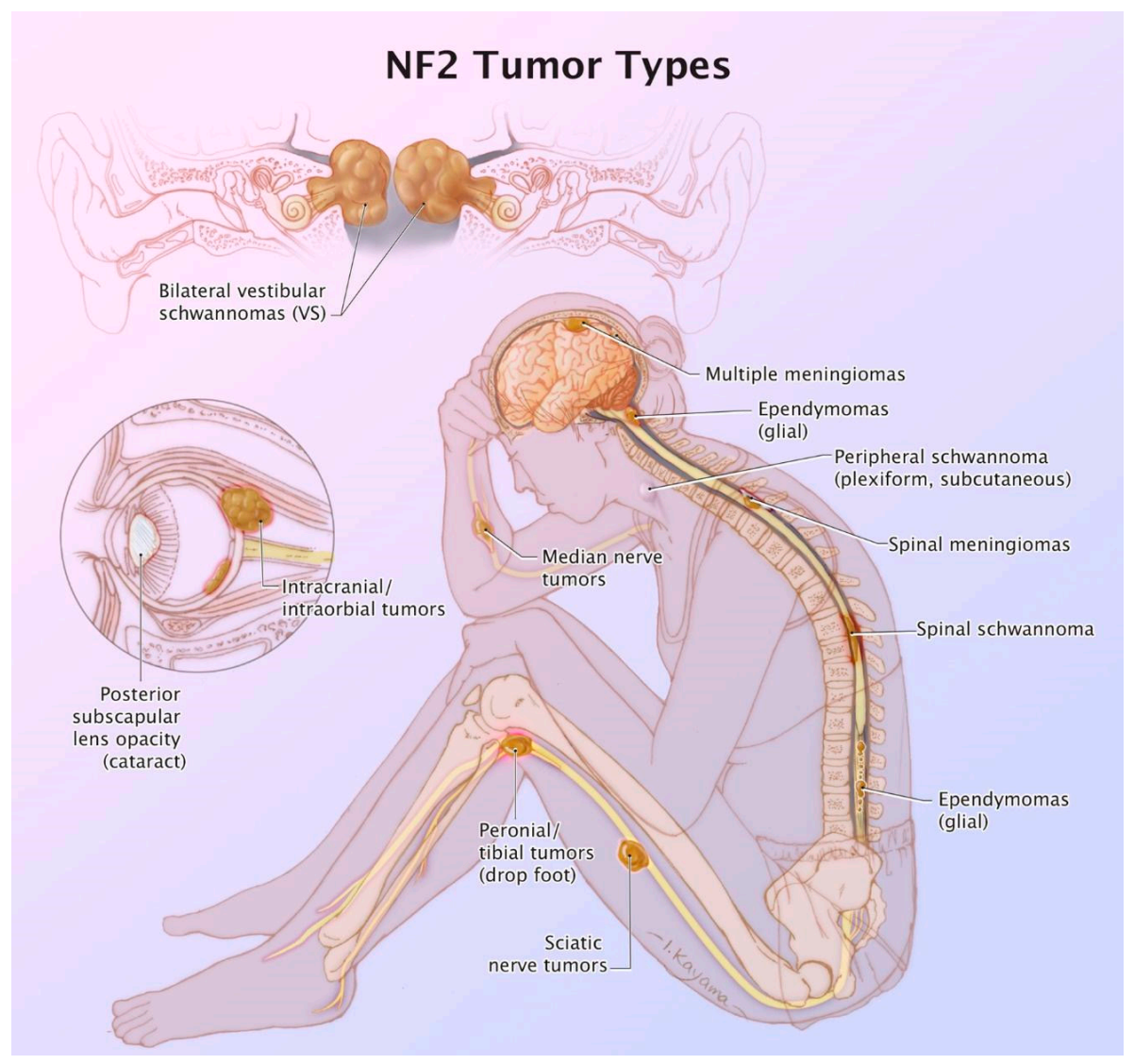

Figure 4. Summary figure of the various morbidities associated with NF2. An original illustration by Ikumi Kayama. 
The molecular pathogenesis of NF2 is complicated by the fact that the loss of function of Merlin, a tumor suppressor protein that interacts with a whole host of integral signaling pathways including Hippo, receptor tyrosine kinase, Ras, MAP kinase (mitogen-activated protein kinase), p21-activated kinases, $\mathrm{PI}_{3}$ Kinase, Focal Adhesion Kinase, CD44, Rac/Rho pathway for cell motility, c-Jun $\mathrm{N}$-terminal kinases, and Wnt. Therefore, targeting Merlin is extremely challenging (reviewed by Coy et al. [20]). Focusing on the molecular aberrations in the multiple meningiomas found in NF2 is still in the process of being unraveled as the genetic profiling of NF2 associated meningiomas is ongoing. However, a recent study compared the molecular profiling of cranial and spinal meningiomas in NF2 [12]. Pemov et al. [12] state that $45-58 \%$ of NF2 patients have intracranial meningiomas and $20 \%$ have spinal meningiomas. They also clarify that meningiomas in NF2 patients are usually benign, WHO Grade 1, and multiple. Unlike sporadic meningiomas, they found a lack of mutations, the most obvious and apparent link is the inactivated NF2 gene. Interestingly, there is an ongoing clinical trial (NCT02523014) that has recently closed to accrual at UCSF looking at GSK2256098 (FAK inhibitor, also a target of Merlin) in NF2 progressive meningiomas.

Meningiomatosis, reviewed by Coy et al. [20], is associated with multiple meningiomas, and genetic analyses of these suggest that they are of clonal origin. These may be rarely associated with malignant sarcomatous lesions, and some patients have been reported to have an absence of germline NF2 or SMARCB1 mutations. In addition, meningiomatosis can demonstrate multiple recurrent chromosomal alterations including monosomy 22, 5q loss, and 6q gain [20]. Meningiomatosis is thought to occur through the silencing of SMARCB1 expression and additional chromosomal alterations. Drugs such as Pazopanib which acts on inhibiting intracellular tyrosine kinase of VEGFR and PDGFR would be an interesting way to treat patients with meningiomatosis, as PDGFR and FGFR pathways are dependent on SMARCB1 loss, and this agent is currently being looked at in a cancer known as atypical teratoid rhabdoid tumor (ATRT) [65].

NF2-related vestibular schwannomas in the recurrent setting are often treated with Bevacizumab [66]. Unfortunately, this often ends up failing, and the INTUITT-NF2 trial (Innovative Trial for Understanding the Impact of Targeted Therapies in NF2, NCT04374305) under the umbrella of the Children's Tumor Foundation and Takeda Pharmaceuticals led by Scott Plotkin (Massachusetts General Hospital) and Jaishri Blakely (Johns Hopkins University) is underway to look at patients with vestibular schwannomas, ependymomas, and meningiomas in the NF2 population. They are currently using Brigatinib, but have a basket trial design, therefore, if the patient's tumor does not respond, they will be eligible for another agent in this trial.

Due to the complexity of care of NF2 patients, and other neurogenetic patients, often clinical centers run a multidisciplinary clinic to address the issues of these patients (Figure 4). NF2 patients tend to be managed by specialized family physicians, neurogeneticists, neurooncologists, neuro-otologists, neurosurgeons, neuro-ophthalmologists, neuroradiologists, social work, audiology, speech therapy, physical therapy, and occupational therapy. As more personalized medicine approaches develop, there will be even more providers involved in the clinical care of NF2 patients who have complex clinical needs. Resources and insurances will all need to align in the increasing costs of taking care of patients with complex needs. However, if there are ways to prevent the morbidities in NF2 patients in the first place, such as gene therapy, morbidity would be less. Attempts are underway to do this. Transgenic murine NF2 models are being utilized to study drugs $[67,68]$. Indeed, MEK 1 and 2 inhibitors are being studied for NF2-related vestibular schwannomas [68]. In addition, one might be able to leverage microsatellite instability in meningiomas [69] and changes in MLH1 and the MSH2 genes may pave the way of trailing immunotherapy in recurrent meningiomas $[23,70]$. As previously discussed in the Children's Tumor Foundation forum, Dr. M. Wootton, CEO of NF2 Therapeutics, mentioned that they have a monkey model of NF2 gene replacement, and based on this, he went on to state that the first human 
clinical trials for this NF2 transgene may start in 2022 or 2023 . Therefore, the future of NF2 is evolving.

Author Contributions: Writing-original draft preparation, S.B., S.S. (Sanjit Shah), S.S. (Scott Shapiro), A.M., and A.K.; Writing—review and editing, A.K. and S.S. (Soma Sengupta); Supervision, R.N.S., M.Z., and E.S. All authors have read and agreed to the published version of the manuscript.

Funding: This research and the APC were funded by the University of Cincinnati, by an endowment through the Harold C. Schott Chair.

Institutional Review Board Statement: The study was conducted according the guidelines of the Declaration of Helsinki, and approved by the Institutional Review Board of the University of Cincinnati (2019-1403).

Informed Consent Statement: Not applicable.

Data Availability Statement: No new data were created or analyzed in this study. Data sharing is not applicable to this article.

Acknowledgments: The authors would like to thank the illustrator, Ikumi Kayama, for Figure 4 and Ady Kendler for the contribution of the neuropathology slide and legend..

Conflicts of Interest: Samy declares a conflict of interest due to research funding from Cochlear Corporation. The funders had no role in the design of the study; in the collection, analyses, or interpretation of data; in the writing of the manuscript, or in the decision to publish the results.

\section{References}

1. Evans, D.G.R. Neurofibromatosis Type 2 (NF2): A Clinical and Molecular Review. Orphanet J. Rare Dis. 2009, 4, 16. [CrossRef]

2. Ruggieri, M.; Praticò, A.D.; Evans, D.G. Diagnosis, Management, and New Therapeutic Options in Childhood Neurofibromatosis Type 2 and Related Forms. Semin. Pediatr. Neurol. 2015, 22, 240-258. [CrossRef] [PubMed]

3. Pećina-Šlaus, N. Merlin, the NF2 gene product. Pathol. Oncol. Res. 2013, 19, 365-373. [CrossRef]

4. Kresak, J.L.; Walsh, M. Neurofibromatosis: A Review of NF1, NF2, and Schwannomatosis. J. Pediatr. Genet. 2016, 5, 98-104. [CrossRef]

5. Tiwari, R.; Singh, A.K. Neurofibromatosis Type 2. In StatPearls; StatPearls Publishing: Treasure Island, FL, USA, 2020.

6. Smith, M.J.; Bowers, N.L.; Bulman, M.; Gokhale, C.; Wallace, A.J.; King, A.T.; Lloyd, S.K.; Rutherford, S.A.; Hammerbeck-Ward, C.L.; Freeman, S.R.; et al. Revisiting Neurofibromatosis Type 2 Diagnostic Criteria to Exclude LZTR1-Related Schwannomatosis. Neurology 2017, 88, 87-92. [CrossRef] [PubMed]

7. Le, C.; Bedocs, P.M. Neurofibromatosis. In StatPearls; StatPearls Publishing: Treasure Island, FL, USA, 2020.

8. Evans, D.G.; King, A.T.; Bowers, N.L.; Tobi, S.; Wallace, A.J.; Perry, M.; Anup, R.; Lloyd, S.K.; Rutherford, S.A.; Hammerbeck-Ward, C.; et al. Identifying the deficiencies of current diagnostic criteria for neurofibromatosis 2 using databases of 2777 individuals with molecular testing. Genet. Med. 2019, 21, 1525-1533. [CrossRef]

9. Li, W.; You, L.; Cooper, J.; Schiavon, G.; Pepe-Caprio, A.; Zhou, L.; Ishii, R.; Giovannini, M.; Hanemann, C.O.; Long, S.B.; et al. Merlin/NF2 Suppresses Tumorigenesis by Inhibiting the E3 Ubiquitin Ligase CRL4DCAF1 in the Nucleus. Cell 2010, 140, 477-490. [CrossRef] [PubMed]

10. Xiao, G.-H.; Chernoff, J.; Testa, J.R. NF2: The Wizardry of Merlin. Genes Chromosomes Cancer 2003, 38, 389-399. [CrossRef]

11. Kluwe, L.; Friedrich, R.E.; Hagel, C.; Lindenau, M.; Mautner, V.-F. Mutations and Allelic Loss of the NF2 Gene in Neurofibromatosis 2-Associated Skin Tumors. J. Investig. Dermatol. 2000, 114, 1017-1021. [CrossRef] [PubMed]

12. Pemov, A.; Dewan, R.; Hansen, N.F.; Chandrasekharappa, S.C.; Ray-Chaudhury, A.; Jones, K.; Luo, W.; Heiss, J.D.; Mullikin, J.C.; Chittiboina, P.; et al. Comparative clinical and genomic analysis of neurofibromatosis type 2-associated cranial and spinal meningiomas. Sci. Rep. 2020, 10, 12563. [CrossRef] [PubMed]

13. Kino, T.; Takeshima, H.; Nakao, M.; Nishi, T.; Yamamoto, K.; Kimura, T.; Saito, Y.; Kochi, M.; Kuratsu, J.-I.; Saya, H.; et al. Identification of the Cis-Acting Region in the NF2 Gene Promoter as a Potential Target for Mutation and Methylation-Dependent Silencing in Schwannoma. Genes Cells 2001, 6, 441-454. [CrossRef] [PubMed]

14. Baser, M.E.; Ragge, N.K.; Riccardi, V.M.; Janus, T.; Gantz, B.; Pulst, S.-M. Phenotypic Variability in Monozygotic Twins with Neurofibromatosis 2. Am. J. Med. Genet. 1996, 64, 563-567. [CrossRef]

15. Baser, M.E.; Kuramoto, L.; Woods, R.; Joe, H.; Friedman, J.M.; Wallace, A.J.; Ramsden, R.T.; Olschwang, S.; Bijlsma, E.K.; Kalamarides, M.; et al. The Location of Constitutional Neurofibromatosis 2 (NF2) Splice Site Mutations Is Associated with the Severity of NF2. J. Med. Genet. 2005, 42, 540-546. [CrossRef] [PubMed]

16. Ruttledge, M.H.; Andermann, A.A.; Phelan, C.M.; Claudio, J.O.; Han, F.Y.; Chretien, N.; Rangaratnam, S.; MacCollin, M.; Short, P.; Parry, D.; et al. Type of Mutation in the Neurofibromatosis Type 2 Gene (NF2) Frequently Determines Severity of Disease. Am. J. Hum. Genet. 1996, 59, 331-342. 
17. Louvrier, C.; Pasmant, E.; Briand-Suleau, A.; Cohen, J.; Nitschké, P.; Nectoux, J.; Orhant, L.; Zordan, C.; Goizet, C.; Goutagny, S.; et al. Targeted next-generation sequencing for differential diagnosis of neurofibromatosis type 2 , schwannomatosis, and meningiomatosis. Neuro Oncol. 2018, 20, 917-929. [CrossRef]

18. Selvanathan, S.K.; Shenton, A.; Ferner, R.; Wallace, A.J.; Huson, S.M.; Ramsden, R.T.; Evans, D.G. Further Genotype-Phenotype Correlations in Neurofibromatosis 2. Clin. Genet. 2010, 77, 163-170. [CrossRef]

19. Pinto, P.S.; Huisman, T.A.; Ahn, E.; Jordan, L.C.; Burger, P.; Cohen, K.J.; Patay, Z.; Tekes, A. Magnetic Resonance Imaging Features of Meningiomas in Children and Young Adults: A Retrospective Analysis. J. Neuroradiol. 2012, 39, 218-226. [CrossRef]

20. Coy, S.; Rashid, R.; Stemmer-Rachamimov, A.; Santagata, S. An Update on the CNS Manifestations of Neurofibromatosis Type 2. Acta Neuropathol. 2020, 139, 643-665. [CrossRef]

21. Kim, K.T.; Lee, C.-H.; Chung, C.K.; Kim, J.H. Is NF2 a Key Player of the Differentially Expressed Gene Between Spinal Cord Ependymoma and Intracranial Ependymoma? World Neurosurg. 2018, 118, e906-e917. [CrossRef]

22. Smirniotopoulos, J.G.; Murphy, F.M. The phakomatoses. AJNR Am. J. Neuroradiol. 1992, 13, 725-746.

23. Proctor, D.T.; Ramachandran, S.; Lama, S.; Sutherland, G.R. Towards Molecular Classification of Meningioma: Evolving Treatment and Diagnostic Paradigms. World Neurosurg. 2018, 119, 366-373. [CrossRef] [PubMed]

24. Karsy, M.; Azab, M.A.; Abou-Al-Shaar, H.; Guan, J.; Eli, I.; Jensen, R.L.; Ormond, D.R. Clinical potential of meningioma genomic insights: A practical review forneurosurgeons. Neurosurg. Focus 2018, 44, E10. [CrossRef] [PubMed]

25. Ostrom, Q.T.; Gittleman, H.; Fulop, J.; Liu, M.; Blanda, R.; Kromer, C.; Wolinsky, Y.; Kruchko, C.; Barnholtz-Sloan, J.S. CBTRUS statistical Report: Primary brain and central nervous system tumors diagnosed in the United States in 2008-2012. Neuro Oncol. 2015, 17, iv1-iv62. [CrossRef] [PubMed]

26. Louis, D.N.; Perry, A.; Reifenberger, G.; Von Deimling, A.; Figarella-Branger, D.; Cavenee, W.K.; Ohgaki, H.; Wiestler, O.D.; Kleihues, P.; Ellison, D.W. The 2016 World Health Organization Classification of Tumors of the Central Nervous System: A summary. Acta Neuropathol. 2016, 131, 803820. [CrossRef] [PubMed]

27. Harter, P.N.; Braun, Y.; Plate, K.H. Classification of meningiomas-advances and controversies. Chin. Clin. Oncol. 2017, 6, S2. [CrossRef] [PubMed]

28. Mirian, C.; Duun-Henriksen, A.K.; Juratli, T.; Sahm, F.; Spiegl-Kreinecker, S.; Peyre, M.; Biczok, A.; Tonn, J.-C.; Goutagny, S.; Bertero, L.; et al. Poor prognosis associated with TERT gene alterations in meningioma is independent of the WHO classification: An individual patient data meta-analysis. J. Neurol. Neurosurg. Psychiatry 2020, 91, 378-387. [CrossRef]

29. Sahm, F.; Schrimpf, D.; Stichel, D.; Jones, D.T.W.; Hielscher, T.; Schefzyk, S.; Okonechnikov, K.; Koelsche, C.; Reuss, D.E.; Capper, D.; et al. DNA methylation-based classification and grading system for meningioma: A multicentre, retrospective analysis. Lancet Oncol. 2017, 18, 682-694. [CrossRef]

30. Goutagny, S.; Bah, A.B.; Henin, D.; Parfait, B.; Grayeli, A.B.; Sterkers, O.; Kalamarides, M. Long-term follow-up of 287 meningiomas in neurofibromatosis type 2 patients: Clinical, radiological, and molecular features. Neuro Oncol. 2012, 14, 1090-1096. [CrossRef]

31. Clark, V.E.; Erson-Omay, E.Z.; Serin, A.; Yin, J.; Cotney, J.; Özduman, K.; Avşar, T.; Li, J.; Murray, P.B.; Henegariu, O.; et al. Genomic Analysis of Non-NF2 Meningiomas Reveals Mutations in TRAF7, KLF4, AKT1, and SMO. Science 2013, 339, 1077-1080. [CrossRef]

32. Bi, W.L.; Greenwald, N.F.; Abedalthagafi, M.; Wala, J.; Gibson, W.J.; Agarwalla, P.K.; Horowitz, P.; Schumacher, S.E.; Esaulova, E.; Mei, Y.; et al. Genomic landscape of high-grade meningiomas. NPJ Genom. Med. 2017, 2, 1-14. [CrossRef]

33. Wallesch, M.; Pachow, D.; Blücher, C.; Firsching, R.; Warnke, J.-P.; Braunsdorf, W.E.; Kirches, E.; Mawrin, C. Altered expression of E-Cadherin-related transcription factors indicates partial epithelial-mesenchymal transition in aggressive meningiomas. J. Neurol. Sci. 2017, 380, 112-121. [CrossRef] [PubMed]

34. Petrilli, A.M.; Fernández-Valle, C. Role of Merlin/NF2 inactivation in tumor biology. Oncogene 2016, 35, 537-548. [CrossRef] [PubMed]

35. Angus, S.P.; Oblinger, J.L.; Stuhlmiller, T.J.; DeSouza, P.A.; Beauchamp, R.L.; Witt, L.; Chen, X.; Jordan, J.T.; Gilbert, T.S.K.; Stemmer-Rachamimov, A.; et al. EPH receptor signaling as a novel therapeutic target in NF2-deficient meningioma. Neuro Oncol. 2018, 20, 1185-1196. [CrossRef] [PubMed]

36. Reuss, D.E.; Piro, R.M.; Jones, D.T.W.; Simon, M.; Ketter, R.; Kool, M.; Becker, A.; Sahm, F.; Pusch, S.; Meyer, J.; et al. Secretory meningiomas are defined by combined KLF4 K409Q and TRAF7 mutations. Acta Neuropathol. 2013, 125, 351-358. [CrossRef]

37. Sahm, F.; Bissel, J.; Koelsche, C.; Schweizer, L.; Capper, D.; Reuss, D.; Böhmer, K.; Lass, U.; Göck, T.; Kalis, K.; et al. AKT1E17K mutations cluster with meningothelial and transitional meningiomas and can be detected by SFRP1 immunohistochemistry. Acta Neuropathol. 2013, 126, 757-762. [CrossRef]

38. Abedalthagafi, M.; Bi, W.L.; Aizer, A.A.; Merrill, P.H.; Brewster, R.; Agarwalla, P.K.; Listewnik, M.L.; Dias-Santagata, D.; Thorner, A.R.; Van Hummelen, P.; et al. Oncogenic PI3K mutations are as common asAKT1andSMOmutations in meningioma. Neuro Oncol. 2016, 18, 649-655. [CrossRef]

39. Bi, W.L.; Abedalthagafi, M.; Horowitz, P.; Agarwalla, P.K.; Mei, Y.; Aizer, A.A.; Brewster, R.; Dunn, G.P.; Al-Mefty, O.; Alexander, B.M.; et al. Genomic landscape of intracranial meningiomas. J. Neurosurg. 2016, 125, 525-535. [CrossRef]

40. Brastianos, P.K.; Horowitz, P.M.; Santagata, S.; Jones, R.T.; McKenna, A.; Getz, G.; Ligon, K.L.; Palescandolo, E.; Van Hummelen, P.; Ducar, M.D.; et al. Genomic sequencing of meningiomas identifies oncogenic SMO and AKT1 mutations. Nat. Genet. 2013, 45, 285-289. [CrossRef] 
41. Goutagny, S.; Kalamarides, M. Meningiomas and neurofibromatosis. J. Neuro Oncol. 2010, 99, 341-347. [CrossRef]

42. Lee, Y.S.; Lee, Y.-S. Molecular characteristics of meningiomas. J. Pathol. Transl. Med. 2020, 54, 45-63. [CrossRef]

43. Al Hinai, Q.; Zeitouni, A.; Sirhan, D.; Sinclair, D.; Melancon, D.; Richardson, J.; Leblanc, R. Communicating Hydrocephalus and Vestibular Schwannomas: Etiology, Treatment, and Long-Term Follow-Up. J. Neurol. Surg. Part B Skull Base 2013, 74, 068-074. [CrossRef] [PubMed]

44. Howitz, M.F.; Johansen, C.; Tos, M.; Charabi, S.; Olsen, J.H. Incidence of vestibular schwannoma in Denmark, 1977-1995. Am. J. Otol. 2000, 21, 690-694. [PubMed]

45. MacCollin, M.; Chiocca, E.A.; Evans, D.G.; Friedman, J.M.; Horvitz, R.; Jaramillo, D.; Lev, M.; Mautner, V.F.; Niimura, M.; Plotkin, S.R.; et al. Diagnostic criteria for schwannomatosis. Neurology 2005, 64, 1838-1845. [CrossRef] [PubMed]

46. Neff, B.A.; Welling, D.B.; Akhmametyeva, E.; Chang, L.-S. The Molecular Biology of Vestibular Schwannomas: Dissecting the Pathogenic Process at the Molecular Level. Otol. Neurotol. 2006, 27, 197-208. [CrossRef] [PubMed]

47. Rouleau, G.A.; Merel, P.; Lutchman, M.; Sanson, M.; Zucman, J.; Marineau, C.; Hoang-Xuan, K.; Demczuk, S.; Desmaze, C.; Plougastel, B.; et al. Alteration in a new gene encoding a putative membrane-organizing protein causes neuro-fibromatosis type 2. Nat. Cell Biol. 1993, 363, 515-521. [CrossRef] [PubMed]

48. Trofatter, J.A.; MacCollin, M.M.; Rutter, J.L.; Murrell, J.R.; Duyao, M.P.; Parry, D.M.; Eldridge, R.; Kley, N.; Menon, A.G.; Pulaski, K.; et al. A novel Moesin-, Exrin-, Radixin-like gene is a candidate for the neurofibromatosis 2 tumor-suppressor. Cell 1993, 72, 791-800. [CrossRef]

49. Jacoby, L.B.; MacCollin, M.; Louls, D.N.; Mohney, T.; Rublo, M.-P.; Pulaski, K.; Trofatter, J.A.; Kley, N.; Seizinger, B.; Ramesh, V.; et al. Exon scanning for mutation of the NF2 gene in schwannomas. Hum. Mol. Genet. 1994, 3, 413-419. [CrossRef]

50. Welling, D.B.; Guida, M.; Goll, F.; Pearl, D.K.; Glasscock, M.E.; Pappas, D.G.; Linthicum, F.H.; Rogers, D.; Prior, T.W. Mutational spectrum in the neurofibromatosis type 2 gene in sporadic and familial schwannomas. Qual. Life Res. 1996, 98, 189-193. [CrossRef]

51. Welling, D.B.; Lasak, J.M.; Akhmametyeva, E.; Ghaheri, B.; Chang, L.-S. cDNA Microarray Analysis of Vestibular Schwannomas. Otol. Neurotol. 2002, 23, 736-748. [CrossRef]

52. Baser, M.E. The distribution of constitutional and somatic mutations in the neurofibromatosis 2 gene. Hum. Mutat. 2006, 27, 297-306. [CrossRef]

53. Martuza, R.L.; Eldridge, R. Neurofibromatosis 2 (bilateral acoustic neurofibromatosis). N. Engl. J. Med. 1988, 318, 684-688. [CrossRef] [PubMed]

54. Kluwe, L.; Mautner, V.F. Mosaicism in sporadic neurofibromatosis 2 patients. Hum. Mol. Genet. 1998, 7, 2035-2051. [CrossRef] [PubMed]

55. Carlson, M.L.; Smadbeck, J.B.; Link, M.J.; Klee, E.W.; Vasmatzis, G.; Schimmenti, L.A. Next Generation Sequencing of Sporadic Vestibular Schwannoma: Necessity of Biallelic NF2 Inactivation and Implications of Accessory Non-NF2 Variants. Otol. Neurotol. 2018, 39, e860-e871. [CrossRef] [PubMed]

56. Parry, D.M.; MacCollin, M.M.; Kaiser-Kupfer, M.I.; Pulaski, K.; Nicholson, H.S.; Bolesta, M.; Eldridge, R.; Gusella, J.F. Germ-line mutations in the neurofibromatosis 2 gene: Correlations with disease severity and retinal abnormalities. Am. J. Hum. Genet. 1996, $59,529-539$.

57. Curto, M.; Cole, B.K.; Lallemand, D.; Liu, C.-H.; McClatchey, A.I. Contact-dependent inhibition of EGFR signaling by Nf2/Merlin. J. Cell Biol. 2007, 177, 893-903. [CrossRef]

58. Scoles, D.R.; Yong, W.H.; Qin, Y.; Wawrowsky, K.; Pulst, S.M. Schwannomin inhibits tumorigenesis through direct interaction with the eukaryotic initiation factor subunit c (eIF3c). Hum. Mol. Genet. 2006, 15, 1059-1070. [CrossRef]

59. Ryu, C.H.; Kim, S.-W.; Lee, K.H.; Lee, J.Y.; Kim, H.; Lee, W.K.; Choi, B.H.; Lim, Y.; Kim, Y.H.; Lee, K.-H.; et al. The merlin tumor suppressor interacts with Ral guanine nucleotide dissociation stimulator and inhibits its activity. Oncogene 2005, 24, 5355-5364. [CrossRef]

60. Rong, R.; Tang, X.; Gutmann, D.H.; Ye, K. Neurofibromatosis 2 (NF2) tumor suppressor merlin inhibits phosphatidylinositol 3-kinase through binding to PIKE-L. Proc. Natl. Acad. Sci. USA 2004, 101, 18200-18205. [CrossRef]

61. Lee, J.-Y.; Kim, H.; Ryu, C.H.; Kim, J.-Y.; Choi, B.H.; Lim, Y.; Huh, P.-W.; Kim, Y.-H.; Lee, K.-H.; Jun, T.-Y.; et al. Merlin, a Tumor Suppressor, Interacts with Transactivation-responsive RNA-binding Protein and Inhibits Its Oncogenic Activity. J. Biol. Chem. 2004, 279, 30265-30273. [CrossRef]

62. Lim, J.Y.; Kim, H.; Jeun, S.-S.; Kang, S.; Lee, K.J. Merlin inhibits growth hormone-regulated Raf-ERKs pathways by binding to Grb2 protein. Biochem. Biophys. Res. Commun. 2006, 340, 1151-1157. [CrossRef]

63. Morrison, H.; Sperka, T.; Manent, J.; Giovannini, M.; Ponta, H.; Herrlich, P. Merlin/Neurofibromatosis Type 2 Suppresses Growth by Inhibiting the Activation of Ras and Rac. Cancer Res. 2007, 67, 520-527. [CrossRef] [PubMed]

64. Wiederhold, T.; Lee, M.-F.; James, M.; Neujahr, R.; Smith, N.; Murthy, A.; Hartwig, J.; Gusella, J.F.; Ramesh, V. Magicin, a novel cytoskeletal protein associates with the NF2 tumor suppressor merlin and Grb2. Oncogene 2004, 23, 8815-8825. [CrossRef] [PubMed]

65. Moreno, N.; Kerl, K. Preclinical Evaluation of Combined Targeted Approaches in Malignant Rhabdoid Tumors. Anticancer Res. 2016, 36, 3883-3887. [PubMed]

66. Plotkin, S.R.; Stemmer-Rachamimov, A.O.; Ii, F.G.B.; Halpin, C.; Padera, T.P.; Tyrrell, A.; Sorensen, A.G.; Jain, R.K.; Di Tomaso, E. Hearing Improvement after Bevacizumab in Patients with Neurofibromatosis Type 2. N. Engl. J. Med. 2009, 361, 358-367. [CrossRef] [PubMed] 
67. Vitte, J.; Gao, F.; Coppola, G.; Judkins, A.R.; Giovannini, M. Timing of Smarcb1 and Nf2 inactivation determines schwannoma versus rhabdoid tumor development. Nat. Commun. 2017, 8, 300. [CrossRef] [PubMed]

68. Fuse, M.A.; Dinh, C.T.; Vitte, J.; Kirkpatrick, J.; Mindos, T.; Plati, S.K.; Young, J.I.; Huang, J.; Carlstedt, A.; Franco, M.C.; et al Preclinical assessment of MEK1/2 inhibitors for neurofibromatosis type 2-associated schwannomas reveals differences in efficacy and drug resistance development. Neuro Oncol. 2019, 21, 486-497. [CrossRef]

69. Pećina-Šlaus, N.; Kafka, A.; Lechpammer, M. Molecular Genetics of Intracranial Meningiomas with Emphasis on Canonical Wnt Signalling. Cancers 2016, 8, 67. [CrossRef]

70. Pećina-Šlaus, N.; Kafka, A.; Bukovac, A.; Vladušić, T.; Tomas, D.; Hrašćan, R. Genetic changes of MLH1 and MSH2 genes could explain constant findings on microsatellite instability in intracranial meningioma. Tumor Biol. 2017, 39, 1010428317705791. [CrossRef] 